Crutckshank, R. . . . . . . . 1965. Medical microbiology, 11th ed., Edin-

Ellis, R. J., Edwards, P. R., AND Fife, 1957. Publ. Hlth Lab., 15, 89. MARY A.

HeiberG, B. . . . . . . . . . . . 1936. J. Hyg., Camb., 36, 114.

Hugh, R., AND LeIrson, E. - . . . . 1953. J. Bact., 66, 24.

Kovacs, N. . . . . . . . . . 1956. Nature, Lond., 178, 703.

Lindenbaum, J., Greenough, W. B., III, 1965. Lancet, 1, 1081.

BENENSON, A. S., OsEASOHN, R., Rizvi, S., AND SAAD, A.

McIntyre, O. R., AND Feeley, J. C.

1965. Bull. Wld Hlth Org., 32, 627.

McIntyre, O. R., Feeley, J. C., GreenOUgh, W. B., III, Benenson, A. S., Hassan, S. I., AND SAAD, A.

MøLler, V. .

1965. Amer. J. Trop. Med. Hyg., 14, 412.

MukerJee, S. . . . . . . . . . . .

POllitzer, R. . . . . . . . . . . .

1955. Acta path. microbiol. scand., 36, 158.

1963. Bull. Wld Hlth Org., 28, 337.

1959. Cholera, World Health Organization Monograph Series no. 43.

SaCk, R. B., Barua, D., SAXena, R., AND 1966. J. Infect. Dis., 116, 630.

CARPENTER, C. C. J.

Sakazaki, R., Gomez, Cecilia Z., And 1967. Jap.J. Med. Sci. Biol., 20, 265.

Sebald, Madeleine

SHEWAN, J. M., Hodgkiss, W., AND 1954. Nature, Lond., 173, 208. LISTON, J.

SMITH, H. L., JR . . . . . . . . 1958. Bact. Proc., p. 69.

Smith, H. L., JR, AND Goodner, K. 1965. Proceedings of the Cholera Research Symposium, January 24th-29th, Honolulu, Hawaii, Washington, D.C., p. 4.

Wilson, G. S., And Miles, A. A. 1964. Topley and Wilson's Principles of bacteriology and immunity, 5th ed., London, vol. 1, pp. 336 and 1002 .

\title{
ANTIBODY TO ONCOGENIC VIRUS IN CANCER PATIENTS
}

\author{
E. SANDRA McFarlane* \\ Department of Microbiology, Dalhousie University, Halifax, Nova Scotia, Canada
}

THE discovery that some human adenoviruses are oncogenic for hamsters (Huebner, Rowe and Lane, 1962; Trentin, Yabe and Taylor, 1962) and that animal oncogenic viruses, such as the simian virus SV40, are not necessarily species-specific (Koprowski et al., 1962) led to a search for evidence of infection with these viruses in cancer patients (Larson, Gasnell and Hilleman, 1967; Rowe and Lewis, 1968; Shah, 1969).

In the present study we looked for complement-fixing antibodies against adenovirus type-12 tumour (T) antigen and SV40 tumour (T) antigen in both cancer patients and control subjects. In the hamster adenovirus-tumour model the presence of complement-fixing antibody against $\mathrm{T}$ antigen has been shown to reflect current antigenic stimulation; the antibody level drops on removal of the tumour (Larson et al.). The presence of this antibody in human serum probably indicates, therefore, either recent infection with the virus or a cancerous condition induced by the virus. 


\section{MATERIALS AND METHODS}

Blood samples were obtained from cancer patients attending the Victoria General Hospital or the Nova Scotia Tumour Clinic, Halifax. Control blood specimens, from patients with non-cancerous diseases in the Victoria General Hospital, were supplied by the Serology Laboratory of the Nova Scotia Pathology Institute. The sera were stored at $-20^{\circ} \mathrm{C}$ until tested.

Complement-fixing (CF) antibodies were estimated as described by Huebner et al. (1963). The adenovirus type-12 $\mathrm{T}$ antigen and the SV40 $\mathrm{T}$ antigen, prepared from tumour-bearing hamsters, were purchased from Flow Laboratories, Rockville, Maryland, USA, and single

TABLE I

Frequency of complement-fixing (CF) antibodies against adenovirus type-12 $T$ antigen in cancer patients and control subjects

\begin{tabular}{c|c|c}
\hline & \multicolumn{2}{|c}{ Number of sera with this titre from } \\
\cline { 2 - 3 } titres & cancer patients & control patients \\
& 543 & 492 \\
$<2$ & 0 & 1 \\
2 & 0 & 2 \\
4 & 0 & 4 \\
8 & 1 & 0 \\
16 & 1 & 0 \\
32 & 1 & 0 \\
64 & 0 & 0 \\
128 & 1 & 500 \\
512 & 548 & 8 (1.6 per cent.) \\
\hline
\end{tabular}

batches were used for all tests. The antigens were diluted for use to contain 2 units, as determined by block titration against positive hamster serum. Control negative antigen consisted of a 20 per cent. extract of hamster embryos, prepared as described by Shaw and McFarlane (1969).

\section{RESULTS}

Sera from 548 cancer patients were tested for $\mathrm{CF}$ antibodies against adenovirus type-12 $T$ antigen. The patients included ten aged $0-15 \mathrm{yr}, 15$ aged $15-25 \mathrm{yr}, 155$ aged $25-40 \mathrm{yr}$ and 368 over $40 \mathrm{yr}$ of age. Only five $(0.9 \mathrm{per}$ cent.) of the sera were positive, with antibody titres ranging from 16 to 512 (table I). The 500 control, non-cancer patients comprised ten aged $0-15 \mathrm{yr}, 20$ aged 15-25 yr, 235 aged 25-40 yr and 235 over $40 \mathrm{yr}$ of age, and of these eight (1.6 per cent.) possessed CF antibodies. Although the incidence of antibodies was not significantly different from that in the cancer patients, the antibody titres were decidedly lower, ranging from 2 to 16.

All the patients having antibody were $40 \mathrm{yr}$ old or younger; the positive cancer patients were aged 11,14, 27, 35 and 38 yr, the controls $8,11,14,15,21,33,35$ and $40 \mathrm{yr}$. Considering only the under-40-yr-old population groups, the incidence of antibody was $2 \cdot 8$ per cent. $(5 / 180)$ in the case of the cancer patients and 3 per cent. $(8 / 265)$ in the controls.

Although a wide range of cancers was studied the positive antibody results were restricted 
to cases of acute lymphatic leukaemia and Hodgkin's disease (table II). The incidence of antibodies, however, in these two conditions was not significantly high.

Sera from 50 cancer patients, including 20 with Hodgkin's disease, 15 with acute lymphatic leukaemia, five with chronic myeloid leukaemia, five with breast cancer and five with urinary tract carcinoma, were tested for the presence of CF antibody against SV40 T antigen, but they were all negative. Fifty control sera, including all those with antibody against the adenovirus $\mathrm{T}$ antigen, were also examined with negative results.

TABLE II

Frequency of complement-fixing antibody against adenovirus type-12 $T$ antigen in patients with various forms of cancer

\begin{tabular}{|c|c|}
\hline Clinical diagnosis & Number positive/number tested \\
\hline $\begin{array}{l}\text { Acute lymphatic leukaemia } \\
\text { Carcinoma of the breast }\end{array}$ & $2 / 66$ \\
\hline $\begin{array}{l}\text { Carcinoma of the breast } \\
\text { Carinoma of genital tract and external } \\
\text { genitalia (female) }\end{array}$ & $\begin{array}{l}0 / 80 \\
0 / 70\end{array}$ \\
\hline $\begin{array}{l}\text { Carcinoma of genital tract and external } \\
\text { genitalia (male) }\end{array}$ & $0 / 56$ \\
\hline Carcinoma and melanoma of skin & $0 / 50$ \\
\hline Carcinoma of urinary tract & $0 / 20$ \\
\hline Carcinoma of head and neck & $0 / 52$ \\
\hline Chronic granulocytic leukaemia & $0 / 44$ \\
\hline Chronic lymphatic leukaemia & $0 / 40$ \\
\hline Chronic myeloid leukaemia & $0 / 30$ \\
\hline Hodgkin's disease . & $3 / 40$ \\
\hline Total & $5 / 548$ \\
\hline
\end{tabular}

\section{DisCusSion}

The frequency of CF antibodies against adenovirus type-12 $\mathrm{T}$ antigen in this survey is much lower than that previously reported by Van Hoosier and Trentin (1968). They found antibodies in 27.7 per cent. of cancer patients and 37.5 per cent. of controls. This discrepancy may be related to the relatively low incidence of adenovirus infections in the Nova Scotia population, as shown by serological studies using the adenovirus group CF antigen (R. S. Faulkner, personal communication; McFarlane, unpublished results). Although we found no obvious difference in the frequency of anti-T antibody between the cancer and control patients it is interesting that high titres were obtained only in some cases of acute lymphatic leukaemia and Hodgkin's disease. However, a much larger number of cases must be investigated, particularly before the start of treatment, before any significant aetiological correlation can be made. The only survey as yet reported describing a positive correlation between the presence of viral antibody and cancer is that of Rawls et al. (1968), who found a significantly high incidence of herpesvirus type- 2 antibodies in cases of carcinoma of the cervix.

A more extensive study is in progress to determine whether the antibodies against adenovirus $\mathbf{T}$ antigen persist in our cancer and control cases.

\section{SUMMARY}

Sera from 548 cancer patients and 500 control subjects were tested for the presence of complement-fixing antibodies against adenovirus type-12 tumour $(\mathrm{T})$ antigen. Five of the cancer patients' sera were positive, with titres ranging from 16 to 512. Eight of the control subjects' sera were positive, with titres ranging from 2 to 16 . No correlation was found 
with sex or socio-economic status, but all the positive sera were from patients $40 \mathrm{yr}$ old or younger. The high titres of antibody were found only in some patients with acute lymphatic leukaemia or Hodgkin's disease. Antibodies against SV40 T antigen were not found.

I am indebted to Mrs Diane MacAuley for excellent technical assistance and to Miss Frances Cook for collecting some of the blood samples. Financial help was received from the National Cancer Institute of Canada and from the Medical Research Council of Canada.

\section{REFERENCES}

Huebner, R. J., Rowe, W. P., ANd Lane, 1962. Proc. Natn. Acad. Sci. USA, 48, 2051. W. T.

Huebner, R. J., Rowe, W. P., Turner, 1963. Ibid., 50, 379.

H. C., AND LANE, W. T.

Koprowski, H., Ponten, J., Jensen, F., 1962. J. Cell. Comp. Physiol., 59, 281.

Raudin, R. G., MOORHEAD, P., AND

SAKSELA, E.

Larson, V. M., Gasnell, P. A., And 1967. Proc. Soc. Exp. Biol. Med., 125, 525. HiLleman, M. R.

RaWls, W. E., Tompkins, W. A. F., 1968. Science, N.Y., 161, 1255.

Figueroa, N. E., AND MELnick, J. L.

Rowe, W. P., AND LEWIS, A. M., JR . 1968. Cancer Res., 28, 1319.

SHAH, K. V. . . . . . . . . 1969. J. Natn. Cancer Inst., 42, 139.

Shaw, G.J., and McFarlane, E. Sandra 1969. Canad.J. Microbiol., 15, 583.

Trentin, J. J., YABE, Y., AND TAYLOR, G. 1962. Science, N.Y., 137, 835.

VAN Hoosier, G. L., JR, AND Trentin, 1968. J. Natn. Cancer Inst., 40, 249. J. J.

Vol. 3, No. 3, August 1970, was issued on 2.11.70. 